\title{
Evaluation of Poverty Reduction Programs in Batam City
}

\author{
Bobby Mandala Putra ${ }^{1}$, Azhar Abbas ${ }^{2}$ \\ ${ }^{1}$ Assistant Professor at Departement of Public Administration, Faculty of Social and Humaniora, Universitas \\ Putera Bata (email: bobby@puterabatam.ac.id), ${ }^{2}$ Assistant Professor at Departement of Public Administration, \\ Faculty of Social and Humaniora, Universitas Putera Batam (email: Azhar.Abbas@puterabatam.ac.id)
}

\begin{abstract}
Poverty is still a severe problem in Indonesia. Statistics show that until the end of 2017, the number of poor people in Indonesia is 26.58 million people or 10.12 percent of the total population. Uniquely, when the poverty rate has decreased in various regions in Indonesia, the poverty rate in Batam has increased. At present, the number of poor people in Batam City is 28,674 families. Although there is a reasonably high interest in poverty, the amount of research in Batam is still limited. The purpose of this study is to describe and analyze poverty reduction programs in Batam City. This research was conducted using qualitative descriptive research. The research proves that the poverty reduction program in Batam City has five impacts on public problems: first, the poverty reduction program has not been able to reduce poverty; second, the target group feels that their lives are better after receiving a poverty reduction program; third, the target group continues to live in poverty; fourth, the target group feels that the state is present in their lives; fifth, the target group has resigned to living in poverty. Besides, poverty reduction programs have two effects on the spillover effect; first, the emergence of social jealousy in the community; second, increase incumbent electability. In closing, this study recommends that poverty reduction programs still need to be continued but need to be revised. The improvement is to provide education and stimulation to recipients of poverty reduction programs so that they can escape poverty.
\end{abstract}

\section{Keywords:}

poverty reduction; program evaluation; public policy evaluation; poverty in Indonesia

\section{Introduction}

The problem of poverty is still severe in Indonesia. Since the old order, the new order, the reform era, and the post-reform era, the problem of poverty has remained one of the main focuses of the government under the command of President Joko Widodo. Seeing the portrait of poverty in Indonesia is very easy because we still encounter many lowincome families both in urban and rural areas. Statistics show that until the end of 2017, the number of poor people in Indonesia is 26.58 million or 10.12 percent of the national population. Even though there was a decrease of 1.19 people from March 2017, it turns out 
that the number of poor people in Indonesia is still more than the population of Australia (Satyagraha, 2018). The number of poor people in the Riau Islands and Batam Provinces is the antithesis of the overall number of poor people in Indonesia, which has decreased. The number of poor people in Riau Islands Province in September 2017 reached 128,462 people or 6.13 percent of the total population, an increase compared to March 2017, which amounted to 125,370 people or 6.06 percent of the total population (Rusdianto, 2018). Based on integrated databases in seven districts/cities in Riau Islands in 2017, it is known that the highest poverty rate in Riau Islands is Batam City, with a total of 28,674 poor households (JPG, 2018).

Indonesia has declared itself a welfare state stating that poverty is a severe public problem and a common enemy that must be appropriately resolved. The central and regional governments have made various efforts to reduce poverty through poverty reduction programs. These poverty reduction programs need a comprehensive evaluation to see how they are affected. Has the poverty reduction program reached its stated goals? What are the costs, and what are the benefits of poverty reduction programs? Who benefits from the poverty reduction programs that have been implemented? These are questions that need to be answered by the government is considering a poverty reduction program, whether the poverty reduction program needs to be continued, revised, or stopped.

Many studies discuss the problem of poverty. These studies can be divided into three main trends. First, research that analyzes the efforts of disadvantaged families in fighting poverty, such as research (Pitoyo \& Alfana, 2015), (Arif Nursaid, 2016), (Fajarwati, Sari, \& Soewarno, 2017) and (Surahmiyati, Yoga, \& Hasanbasri, 2017). Second, research that discusses poverty conditions in Indonesia, especially in eastern Indonesia such as research (Dedi Dhosa, 2017), (Ermasari, Sukamdi, \& Tukiran, 2010), and (Leslie \& Hardyastuti, 2011). Third, research that discusses factors that influence poverty, such as research (Permana, 2016), (Zuhdiyaty \& Kaluge, 2017), (Roso Wulandari, 2016), and (Prastyo, 2010).

There is a high level of interest in the problem of poverty, as explained above. However, unfortunately, only a few researchers or scientists are interested in examining the problem of poverty from a public policy perspective, especially looking at the impact of poverty reduction programs in Batam City. The researchers in question are (Mahaeni et al., 2011), (Romus, 2014), (Murdiansyah, 2014), (Kurniawan, Wijaya, \& Domai, 2014), and 
(Saptono et al., 2013). Poverty reduction programs that have been and are being implemented will require evaluation so that the impact of poverty reduction programs can be understood.

The lack of policy research accurately evaluating poverty reduction programs is certainly sad because poverty rates in Indonesia are still high, especially in Batam City, which has increased. The government needs the results of research related to the evaluation of poverty reduction programs as the policy actor responsible for solving the problem, researchers, lecturers, and students who are interested in policy studies, especially evaluation of public policy.

Based on the background of the problems outlined above, the main problem to be examined in this study is how the impact of poverty reduction programs in Batam City. However, the poverty reduction program in question is limited to the Family Hope Program, the Rehabilitation Program for Non-Habitable Homes, the Healthy Indonesia Card, the Smart Indonesia Card, and the Cheap Food Aid Program.

This research seeks to contribute knowledge by presenting descriptions and explanations about the impact of poverty reduction programs in Batam City. The results of this study can be used as a consideration to determine the policy direction of poverty reduction programs in Indonesia, especially in the city of Batam in the future, including in providing recommendations on whether poverty reduction programs that have been implemented need to be continued, revised or stopped.

\section{Literature Review}

Easton defines public policy as the authoritative allocation of values for the whole society. Laswell and Kaplan define public policy as a projected program of goals, values, and practices. Pressman and Widavsky define public policy as a hypothesis containing initial conditions and predictable consequences (Taufiqurokhman, 2014).

James Anderson defines public policy as the direction of action taken by an actor or some actors to solve a problem or problem. Thomas R. Dye defines public policy as whatever the government chooses to do or not do. Riant Nugroho defines public policy as a decision made by the state, especially the government, as a strategy to realize the country's goals. Based on several definitions of the public policy above, it can be concluded that public 
policy is the government's decision in realizing the goals of the country through development strategies in the short, medium and long term in the fields of ideology, politics, economy, social culture, defense, and security.

If public policy is seen as a sequential pattern of activities, policy evaluation is the final stage in public policy, although not all policy experts agree with the statement. In general, policy evaluation aims to assess the effectiveness and impact of public policy. Effectiveness is related to the level of achievement of a policy goal and impact related to changes in behavior or conditions of the target group of the policy after intervention by the policy. The final result of a policy evaluation will produce a conclusion that is whether the policy needs to be continued, corrected, or terminated. Thus, policy evaluation is an activity to assess a policy product both in terms of formulation (content), implementation, and impact of the policy.

According to Lester and Stewart (Winarno, 2016), policy evaluation can be divided into two different tasks. The first task is to determine the consequences of a policy by describing its impact, while the second task is to assess the success or failure of a policy based on predetermined standards or criteria. Thus policy evaluation is a matter of fact in the form of measurement and assessment both of the stages of the implementation of the policy and the outcome (outcome) or the impact (impact) of the operation of a particular policy or program, thus determining the steps that can be taken in the future.

James Anderson in (Winarno, 2016) divides policy evaluation into three types, each type of evaluation that is introduced is based on the evaluators' understanding of the evaluation, as follows:

a) The first type

Policy evaluation is understood as functional activity. If policy evaluation is understood as a functional activity, policy evaluation is seen as an activity that is as important as the policy itself.

b) The second type

It is a type of evaluation that focuses on the operation of particular policies or programs. This type of evaluation talks more about honesty or efficiency in implementing programs.

c) The third type 
The type of systematic policy evaluation, this type of policy evaluation looks objectively at the policy programs implemented to measure their impact on society and see the extent to which the stated objectives have been achieved.

Evaluating the impact of a program or public policy requires the existence of criteria so that the results of measuring the success of the program or public policy are credible and can be accounted for. To conduct a proper policy evaluation with a minimum margin of error, some experts make steps in policy evaluation. One such expert is Edward A. Suchman. Suchman stated the six steps of policy evaluation, namely (1) identifying the objectives of the program to be evaluated; (2) analysis of the problem; (3) description and standardization of activities; (4) measurement of the level of change that occurs; (5) determine whether the observed change is a result of the activity or due to other causes; (6) several indicators to determine the existence of an impact.

In this research, the author simplifies and perfects the steps of policy evaluation according to Suchman and replaces some terms that are not quite right. This was done because the steps that Suchman had put forward were inaccurate, ambiguous, ambiguous, inaccurate, and had explanations that were not operational so that they had explanations that could not be understood technically and could be confusing for policy evaluators in evaluating policies in the field. The following is an explanation of the steps for policy evaluation, according to Schuman, whose researchers are inaccurate, confusing, ambiguous, inaccurate, and have non-operational explanations. First, Schuman said that the first step in evaluating the first policy was to identify the objectives of the programs to be studied. In this step, Schuman uses the term that is not appropriate, which is the program, but what Schuman discusses is policy, so the term program becomes irrelevant because, in reality, programs and policies have differences even though the program is a derivative of policies. One difference is the scope. Policies have a broader scope because one policy can consist of several programs or projects. Second, analysis of the problem. This second step is also considered confusing because when identifying the objectives of the policy or program, it will indirectly discuss the issue of the policy. So making the identification of policy or program objectives separate from the analysis of the problem is a mistake and confuses policy evaluators, especially novice evaluators. Third, the description and standardization of activities are ambiguous and unclear. Sentence The description and standardization of this 
activity need to be replaced with sentences or terms that are easier to understand. Fourth, separating the measurement step against the level of change that occurs and the step determining whether the observed change is a result of the activity or because other causes are inaccurate and is a mistake because the substance of the two are interrelated so that it can be simplified. In other words, when measuring the level of change that occurs, the evaluator can directly determine whether the change occurred as a result of policy intervention or not. The separation will only make the evaluator confused. Fifth, the final step is that several indicators to determine the existence of an impact have an explanation that is not operational enough to potentially confuse the policy evaluator. Based on the rationalization above, the researchers made changes and refined the policy evaluation steps according to Schuman into three steps, namely:

1. Identify the policy or program objectives to be evaluated. At this stage, the evaluator identifies the policy or program objectives to be evaluated. The clearer the objectives of the policy or program to be evaluated, the better and easier for evaluators to do the next steps. The purpose of this policy or program is usually stated in the consideration and content of the policy or program product to be evaluated. Besides, evaluators can find out the purpose of the policy or program by conducting a literature study and conducting interviews with formulators, implementors, and stakeholders related to the policy or program to be evaluated. In this study, the objectives of the poverty reduction program are twofold: alleviating the burden on low-income families in the economic field, maintaining the purchasing power of the poor, reducing the quantity and quality of low-income families.

2. Establish evaluation criteria and indicators. At this stage, the evaluator must establish criteria and indicators. To see the effectiveness of the policy, the evaluator needs to set valid policy criteria along with the indicators. Likewise, if the evaluator wants to see the impact of the policy, then the evaluator needs to set the impact criteria and their indicators. In this study, the criterion for the impact of poverty reduction programs is the change desired by the target group, and the indicators are the amount of poverty, the quality of poverty, and the potential to escape from the predicate of low-income families. 
3. Conduct an evaluation of the policy using evaluation criteria or evaluations. At this time, evaluators conduct policy assessments that are evaluated on policy criteria through their indicators.

These policy evaluation steps were carried out by researchers in evaluating poverty reduction programs in Batam City.

\section{Poverty Reduction Programs}

The word program in the Big Indonesian Dictionary is interpreted as a draft of the principles and the business to be carried out. The program is a plan that involves various units that contain policies and a series of activities that must be carried out within a specified period. According to Arikunto (Yendriwalis, 2015), there are two definitions of the term program, namely specific and general understanding. In general terms, the program can be interpreted as a plan. A program is not just a single activity that can be completed in a short time but is continuous because it implements a policy (Yendriwalis, 2015).

Poverty comes from the original word "poor." The word "poor" in the Big Indonesian Dictionary is interpreted as not having wealth; completely lacking (meager income). Poverty is then interpreted as a thing, condition, or situation that is not valuable; completely lacking (meager income). The United Nations Development Program (UNDP) defines poverty as hunger, lack of shelter, inability to go to the doctor if sick, do not have access to school and are illiterate, do not have a job, fear of the future, live on a daily basis, inability to get clean water, powerlessness and lack of representation and freedom. Meanwhile according to Government Regulation No. 42 of 1981, the poor are people who have no source of livelihood and cannot meet basic needs that are appropriate for humanity or people who have a livelihood but cannot meet basic needs that are worthy of humanity (Murdiansyah, 2014)

People who are categorized as poor are those who earn income below the poverty line. The poverty line that is generally set by the government has a dynamic nature, meaning that it always develops or increases, which can be caused by inflation or other factors such as the increase in standards used (Mahaeni et al., 2011). Currently, the government uses a poverty line of Rp. 387,160 per capita per month. Based on the poverty line, Indonesia's poverty rate as of September 2017 reached 26.58 million people. However, if calculated according to World Bank standards, the number of poor people in Indonesia could double the number 
released by BPS because the World Bank poverty line is USD 1.9 per day or the equivalent of Rp775,200 per month (exchange rate of 13,600).

Poverty reduction programs in this study are poverty reduction programs implemented in Batam City, both programs initiated and financed by the central government and those initiated and financed by the Batam City Government. The following is a brief explanation of the poverty reduction programs discussed in this study.

Family Hope Program (FHP)

The Family of Hope Program, after this referred to as FHP, is a program of providing qualified social assistance to Poor Families, which is designated as a family of FHP beneficiaries. As an effort to accelerate poverty reduction, since 2007, the Government of Indonesia has implemented FHP. The Social Protection Program, also known internationally as the Conditional Cash Transfers (CCT), has proven to be quite successful in overcoming poverty faced in these countries, especially the problem of chronic poverty.

As a conditional social assistance program, FHP opens access to needy families, especially pregnant women and children, to utilize various health service facilities and educational service facilities available around them. The benefits of FHP have also begun to be encouraged to include people with disabilities and older adults by maintaining their level of social welfare following the mandate of the constitution and the President's Nawacita. Through FHP, FHP beneficiaries are encouraged to have access to and utilize essential social services in health, education, food and nutrition, care, and assistance, including access to various other social protection programs, which are complementary sustainably. FHP is directed to become an epicenter and center of excellence for poverty reduction that synergizes various national social protection and empowerment programs. FHP's big mission to reduce poverty is increasingly prominent, considering that the number of poor people in Indonesia until March 2016 was still 10.86\% of the total population of 28.01 million people. The government has set a poverty reduction target of $7-8 \%$ by 2019 , as stated in the 2015-2019 national medium-term development plan. FHP is expected to contribute significantly to reducing the number of poor people, reducing the gap (Gini ratio) while increasing the Human Development Index (HDI). The results of other studies show that FHP has an impact on changes in household consumption, as in some other CCT 
implementing countries. FHP has succeeded in increasing the consumption of beneficiary households in Indonesia by $4.8 \%$.

FHP beneficiary families must be registered and present at the nearest health and education facility. Obligations of FHP beneficiaries in the health sector include the examination of the womb for pregnant women, provision of nutritional intake and immunization as well as weighing the body of children under five and preschool children. In contrast, FHP beneficiaries in the field of education must register and insure the presence of family members of FHP recipients to the education unit according to elementary and secondary school levels. Then, for social welfare components, for persons with disabilities and elderly who are at least 60 years old.

FHP social assistance in 2019 is divided into two types, namely Permanent Assistance and Component Assistance provided with the provisions in the following table:

\begin{tabular}{lc}
\hline \multicolumn{2}{l}{ Permanent Assistance for Every Family } \\
\hline Reguler & IDR. 550.000,- / Family / year \\
\hline FHP Access & IDR.1.000.000,- / Family / year \\
\hline \multicolumn{2}{l}{ Assistance component for everybody in a beneficiary family } \\
\hline Pregnant Women & IDR. $2.400 .000,-$ \\
\hline Play Group & IDR. $2.400 .000,-$ \\
\hline Elementary School & IDR. $900.000,-$ \\
\hline Junior High School & IDR. $1.500 .000,-$ \\
\hline Senior High School & IDR. 2.000 .000 \\
\hline Permanent Disability & IDR. $2.400 .000,-$ \\
\hline Elderly People & IDR. $2.400 .000,-$ \\
* Component assistance is given a maximum of 4 people in one family
\end{tabular}

\section{Indonesia Healthy Card (IHC)}

Based on data from the Indonesia Health Insurance Agency (BPJS Kesehatan), the number of participants registered in the National Health Insurance Program - Indonesia Healthy Card (IHC) has reached 216,152,549 people or covering $82 \%$ of Indonesia's total population as of January 10, 2019. The program National Health Insurance - Health BPJS now holds a healthy Indonesia Card (IHC).

IHC is a program initiated by President Joko Widodo and Vice President Jusuf Kalla to provide health protection to the community and reduce their burden in bearing health costs. IHC functions to provide health insurance to the public to get free health services. IHC can be used in every first and advanced health facility. The presence of IHC aims to expand the 
benefits of the Health BPJS Health program launched by the government of Susilo Bambang Yudhoyono (SBY) on March 1, 2014.

Even though the two regions are health facility programs, in reality, IHC and BPJS Health have differences. The main difference is seen in the target or recipient. If BPJS Health is a program whose members have to register and pay contributions, then IHC members are drawn from disadvantaged communities, and the government determines the card. The government also bears payment of IHC contributions. Besides, IHC can be used anywhere, whether in clinics, health centers, or hospitals in Indonesia. The use of BPJS Health only applies to clinics, health centers, or hospitals that have been registered. Another benefit that distinguishes IHC from Health BPJS is that IHC is used not only for treatment but can also be used for prevention. Meanwhile, BPJS health can only be used if a participant's health condition is ill or must be treated.

Indonesia Smart Card (ISC)

Indonesia Smart Card (ISC) is the provision of education cash assistance to schoolage children (aged 6-21 years) who come from poor, vulnerable poor families: the owner of the Prosperous Family Card, participants of the Family Hope Program (FHP), orphans, people with disabilities, and victims of natural disasters / calamities. ISC is part of improving the Poor Student Assistance program. ISC Target Groups are ISC holder learners; Students from poor/vulnerable poor families with special consideration; Vocational students who study group expertise in the fields of Agriculture, Fisheries, Animal Husbandry, Forestry, Shipping, and Maritime.

The Smart Indonesia Card Organizer is a collaboration of three ministries, namely the Ministry of Education and Culture (Kemendikbud), the Ministry of Social Affairs (Ministry of Social Affairs), and the Ministry of Religion (Kemenag) which aims to help school-age children from poor/vulnerable poor / priority families still get services education to graduate from secondary education, either through formal education channels (from elementary / MI to high school / vocational / MA) and non-formal education (Package A to Package $C$ and standardized courses).

Through this program, the government seeks to prevent students from dropping out of school and is expected to be able to attract dropouts to return to continue their education. PIP is also expected to ease the personal costs of education of students, both direct and 
indirect costs. ISC is given as a marker/identity for PIP education aid recipients. This card gives guarantees and certainty that school-age children are registered as recipients of educational assistance. Each child receiving Indonesia Smart Program education assistance is only entitled to 1 (one) ISC. The amount of the ISC benefit fund is as follows:

1. Elementary school students get IDR 450,000 / year

2. Junior school students get IDR 750,000 / year

3. Senior high school students get IDR 1,000,000 / year

The obligations of ISC fund recipient students are as follows:

1. Keep and maintain ISC properly;

2. The benefit fund must be used for relevant purposes;

3. Continue to study and attend school (not dropping out of school) with diligence, discipline, and perseverance.

ISC funds can be used to help students' costs, such as buying school supplies/courses, pocket money, and transportation costs, additional practice fees, and competency test fees. Inadequate House Renovation Program (IHRP)

This program is a poverty reduction program that is budgeted in the Batam City Budget. This program has been started since 2011, and no less than 6 thousand houses have been renovated. In 2015 this program was later adopted by the central government as the Self-Help Housing Stimulant Assistance (SHHSA) program. If the SHHSA program is a national program whose budget is allocated from the APBN and organized by the Ministry of Public Works and Public Housing as the responsible person, then this uninhabitable housing renovation program is a localization poverty reduction program whose budget is allocated from the Regional Revenue Budget (APBD) of Batam city. However, the substance of this program is the same, namely providing renovation assistance to low-income families whose houses are considered unfit for habitation. The amount of funds for housing renovation is not suitable for habitation, around 15-22 million per house.

Cheap Basic Food Assistance Program in Batam City

This low-cost food assistance program is a poverty reduction program budgeted from the Batam city budget. Batam City Government consistently provides cheap food assistance programs twice per year, namely at the beginning of the year and at the end of the 
year. In 2019, the Batam city government will prepare 128 thousand packages of nine basic staples (basic needs) that are distributed to disadvantaged people.

The distribution of cheap food is carried out every before Ramadhan and the end of the year to ease the burden on the community in celebrating Eid, Christmas, and the turn of the year. In a cheap food package, there are $5 \mathrm{~kg}$ of rice and 2 liters of cooking oil. The package worth Rp.89,250 can be owned by the community by paying Rp.50,000; the difference is subsidized by the Batam City Government. The food packages were distributed in turns throughout the villages in the city of Batam. Basic food packages of Sagulung Subdistrict are 2,235 packages for residents of Tembesi Village, 2,220 packages for residents of Sei Langkai Village, 1,613 packages for residents of Sei Pelunggut Village, 1,500 packages for Sei Lekop residents, 1,501 packages for Sei Binti residents and 2,020 packages for Sagulung City residents.

\section{Methods}

This research is descriptive qualitative research that uses independent variables as an answer to the problem formulation by interpreting the data from the field findings. This study will evaluate poverty reduction programs in Batam City with a focus on the impact of the Family Hope Program (FHP), the Healthy Indonesia Card (IHC), the Smart Indonesia Card (ISC), the Inadequate Housing Renovation Program (IHRP) and The Cheap Basic Food Assistance Program.

Primary data obtained by researchers by plunging directly into the research field. Research in the field was conducted to obtain empirical data and facts. In this field, research researchers become good listeners, good observers, and good writers. As a good listener, the researcher listens to all the information that the informant conveys to the researcher using the help of interview guidelines. As a good observation, researchers make observations or observations in the field with the help of a camera or recording device. As a good writer, researchers write what researchers hear and see in the field as objectively as possible using the help of field notes. Secondary data is research supporting data. This data was obtained from research reports and documents relating to the evaluation of poverty reduction programs implemented in Batam City.

Informant Selection Techniques 
In this study using purposive sampling technique. According to (Sugiyono, 2016) Purposive sampling is a sampling technique with specific considerations. The selection of purposive samples is the choice of who is in the best position to provide the information needed. Therefore, determining the chosen subject or people must be following the particular characteristics of the sample. They were chosen because they are believed to represent specific populations. Before determining who becomes the informant in this study, researchers first determine the criteria. The following are the criteria of the informants in this study:

1. Understand and understand research problems, namely the problem of poverty and poverty reduction programs in Batam

2. Directly involved in poverty reduction programs in Batam City, either as recipients of assistance/programs or as party distributors/implementers of programs or policies.

3. Willing to take the time to be interviewed

4. It can be trusted and able to provide data or information objectively.

Based on these criteria, the informant is determined. The following are informants in this study:

1. Head of Poor Handling Division of the Social Service and Community Empowerment of Batam City

2. Head of Batam City Social Service and Community Empowerment Program Sub-Division Head.

3. Batam City Social Service staff who handle BDT (Integrated Database) data

4. Beneficiaries/poverty reduction programs in Batam in various districts and villages in Batam City.

Data analysis

In this study, qualitative data analysis is used and follows the concept of Miles and Huberman (Sugiyono, 2016), known as interactive models. Data analysis is carried out either through procedures or through several stages, namely Data Reduction, Data Presentation, and Conclusion / Verification Drawing.

Description of Research Locations 
Batam City is the largest city in Riau Islands Province, Indonesia, with a land area of $715 \mathrm{~km}^{2}$, and an overall area of 1,575 $\mathrm{km}^{2}$. Batam City Region consists of Batam Island, Rempang Island, and Galang Island and other small islands in the Singapore Strait and Malacca Strait regions. The Barelang Bridge connects Batam Island, Rempang, and Galang. According to the Batam City, Population and Civil Registry Service as of 2015, the population of Batam reached 1,037,187 inhabitants. Batam is part of the Batam-BintanKarimun (BBK) free trade area.

Batam is a city with a very strategic location. Besides being on an international shipping lane, this city has a very close distance and is directly bordered by Singapore and Malaysia. As a planned city, Batam is one of the fastest-growing cities in Indonesia. When it was built in the 1970s by the Batam Authority (currently called BP Batam), the city was inhabited by only around 6,000 residents. Within 40 years, the population of Batam grew to 158 times. Batam city in the north is bordered by the Singapore and Singapore strait, in the south, it borders Lingga Regency, in the west, Karimun Regency borders it. In the east, it is bordered by the islands of Bintan and Tanjung Pinang.

Batam City Community is a heterogeneous society consisting of various tribes and groups. Dominant tribes include Malay, Javanese, Batak, Minangkabau, and Chinese. With an umbrella in Malay culture and upholding Bhinneka Tunggal Ika, Batam has become conducive to driving economic, socio-political, and cultural activities in society. As of April 2012, Batam had a population of 1,153,860 people and had a very high population growth rate. Between 2001 and April 2012, the population growth rate averaged more than 8 percent per year.

\section{Results and Discussion}

The impact of poverty reduction programs in this study will be explained in two dimensions, namely the impact of policies/programs on public problems and on the target group and the impact of policies/programs on circumstances or groups outside the target group or commonly referred to as abundant impacts (externalities or overflow effect). The following is a description and explanation of the impact of poverty reduction programs in Batam City. 
Impact of Policies/Programs on Public Issues and Target Groups

Based on interviews, observations, and documentation, it is known that the target groups in this poverty reduction program are poor people or low-income families. These Target Groups are selected and determined based on the Integrated Database Data (IDD). The integrated database is regularly monitored, updated, or updated. The integrated database can be updated based on the results of monitoring by field officers if there are differences between the data in the system and the data in the field. Besides, the integrated database can be updated if there are reports from the community or extension agents for poverty reduction that there are poor people who have not been included in IDD, or there are people who are not eligible or no longer eligible to enter IDD.

Furthermore, based on the results of interviews, observations, and documentation, researchers found social facts that show that the impact of poverty reduction programs in Batam City on public issues or target groups are as follows:

Poverty Reduction Program Interventions Have Not Been Able to Reduce Poverty in Batam.

Although various poverty reduction programs have been implemented in Batam, unfortunately, this poverty reduction program has not shown satisfactory results. The results showed that the poverty level in Batam increased. In the last three years, the number of poor people in Batam has increased significantly. In 2016 there were 57,290 people, then in 2017 , it rose to 61,161 people. Then in 2018 , there were 67,413 people or an increase of 6,252 people from the previous year. Various factors influence the increasing number of poor people. However, aside from intervention in poverty reduction programs that are considered not able to reduce poverty in Batam, the trend of increasing poverty in Batam City is also influenced by urbanization flows, slowing economic growth in Batam, and many foreign companies going bankrupt or moving from Batam.

So, based on the facts found that poverty reduction programs, namely the Family Hope Program (FHP), the Healthy Indonesia Card (IHC), the Smart Indonesia Card (ISC), the Inadequate Housing Renovation Program (IHRP) and Cheap Basic Food Assistance Program in Batam City has not been able to reduce the number of poor families in Batam. One of the factors that caused it was that in the implementation phase, it was still found that the target groups that actually did not meet the requirements to get or receive poverty 
reduction programs actually accepted, while poor families who were very worthy of receiving or getting the poverty program actually did not receive or get it.

The Target Group Feels Their Life is Better After Receiving a Poverty Reduction Program.

Poverty reduction programs, namely the Family Hope Program (FHP), the Indonesia Healthy Card (IHC), the Smart Indonesia Card (ISC), the Uninhabitable Home Renovation Program (UHRP) and the Cheap Food Assistance Program, have proven to be quite useful in easing the economic burden of low-income families. The researcher found social facts in the field that the target group (low-income families) who received poverty reduction programs were quite helped by the poverty reduction program they received. Even though the amount of assistance in the form of money, goods, or services they received has not been able to meet all their daily needs, but they claim to be happy because they feel their lives are better after receiving a poverty reduction program.

Facts on the field show that the target group (low-income families) still have difficulty meeting their daily needs even though they have become beneficiaries of poverty eradication programs. However, it will be even more complicated when the money or goods they should receive come too late from the specified schedule. Not a few of them are indebted to relatives, neighbors, and friends to meet their daily needs. See this reality, and the researcher concludes that the benefits received by the target groups for poverty reduction programs need to be increased because the amount currently received is not sufficient to meet all the needs of the low-income family's life, let alone stimulate, so those poor families become productively. The government should increase the benefits of poverty reduction programs because it has become its responsibility, as stated in the constitution. Besides, poverty reduction programs should be able to solve problems substantially not only as political imagery as if the state is present, but their presence does not contribute maximally in reducing poverty.

The Target Group Continues to Live in Poverty

Although the target groups (low-income families) feel helped by poverty reduction programs in meeting their daily needs, they have not been able to escape from the poverty line. Facts on the ground show that not one single poor family in Batam City has managed to get out of the poverty trap after receive or get poverty reduction programs such as the Family Hope Program, the Smart Indonesia Card, the Healthy Indonesia Card, the Basic 
Staple Assistance Program, and the Uninhabitable Home Rehabilitation Program. One of the FHP recipients in the Sagulung District of Batam City claimed to have received the FHP for years. However, during that time, he also lived in poverty. Likewise, the recipients of other poverty reduction programs also remain poor and fail to get out of the vicious cycle of poverty.

The researcher asses that the poverty reduction programs mentioned above do not exclude the target group from the poverty line because of two main things. First, the poverty reduction programs substantially do not educate and stimulate the target groups or poor families to move out of poverty. These programs only have a short-term goal of alleviating the burden on the lives of low-income families so that the target group does not receive an adequate education. This is evidenced by the majority of the target group that regards the problem of poverty as a destiny that cannot be changed. Besides, poverty reduction programs are not able to stimulate the target group to be more productive. As a result of the lack of education and stimulation in poverty reduction, the majority of target groups are resigned to poverty and have no hope of escaping poverty. Their only hope is that their children will be able to escape poverty. Second, the implementation of poverty reduction programs that are still not good enough. The implementation of the program is crucial for the success of a program to achieve the desired impact. In this study, researchers found that there were still incorrect target groups.

Inaccurate because it does not meet the criteria established as program recipients. Still found there are recipients of poverty reduction programs that are quite capable economically but still get. In Batam's Nongsa sub-district, there is one recipient of a family hope program that has a pretty good house and has a car. In another sub-district, it was found that there were impoverished families who did not get even one poverty reduction program. She is a widow as well as the backbone of the family, does not have a home, does not have a car, and lives in deprivation. This is a portrait of how the implementation of poverty reduction programs is not good enough. Therefore, poverty reduction programs will not be effective in reducing the number of poor people if there are still many target groups that do not receive the poverty reduction program.

The Target Group Feels That the State Is Present in Their Lives 
The target group or recipients of poverty reduction programs in Batam are happy because they have obtained the program even though the amount of benefits provided in the form of money, goods, or services is not able to meet all their daily needs. They feel happy because they feel the state has been present in their lives, even though the actual presence of the state is a necessity because the constitution has mandated it. The constitution states that orphans, the poor, are cared for by the state, so what the government has done in reducing poverty is a necessity and a necessity. However, all informants interviewed by researchers felt grateful that the state had paid attention to their lives as poor people and did not question whether the presence of the state in their lives was a necessity or not.

Politically this poverty reduction program is beneficial for incumbents, both the president, governors, and regents/mayors because this program gets good appreciation from the community, especially the target group. This good appreciation automatically increases the electability of incumbents both at the regional level (governors and regents/mayors) and at the center, namely the president among the target group. Researchers found social facts that the majority of the target group did not know the origins of poverty reduction programs, including the sources of funding for poverty reduction programs, so that they considered all incumbents to be able to receive their gratitude. One form of reciprocation is to give their political rights to incumbents both at the level and in the ballot box at the time of the general election.

The Target Group Has Resigned Themselves to Living in Poverty

Based on the results of interviews and observations in the field, researchers found interesting social facts. Researchers found that most of the target groups or low-income families that received poverty reduction programs had resigned themselves to poverty and considered poverty to be a destiny that could not be changed. There are even recipients of poverty reduction programs that are not only resigned to their "poor status" but are already "enjoying poverty." This is evidenced by a middle-aged woman recipient of a poverty program in Batam living with two children and a husband. Although physically, she and her husband are still able to work, and their ages are still productive, they are reluctant to work like other families in general. They rely on money or goods from poverty reduction programs to meet the costs of their daily lives. The house is still dirt-floored and living in deprivation does not make them eager to get out of the inferior zone. They assume that 
poverty is destiny and not for them to reject. They only hope that one day, their children will get out of the poverty line.

The above conditions show that the poverty reduction programs referred to in this study do not provide education and stimulation to the target group so those poor families can get themselves out of poverty. Therefore, these poverty reduction programs cannot be expected to reduce poverty effectively and massively in the future. These programs only help low-income families in alleviating the burden of living for needy families, so that lowincome families do not get more miserable. In the long run, poverty reduction programs like this can give birth, influence, or increase the amount of cultural poverty. If this happens, the problem of poverty in Indonesia will be increasingly difficult to overcome because poverty is no longer caused by economic factors but is caused by poor behavior, lifestyle, and mentality.

\section{The emergence of Social Jealousy in the Community}

The first externality effect is the emergence of social jealousy in the community. Social facts on the ground show that many underprivileged families who do not receive poverty reduction programs feel jealous. This is not unreasonable, because, in the field, it is found that many poor families whose homes are close to the recipients of poverty reduction programs do not get any poverty reduction programs. In fact, some families are poorer than the families that receive poverty reduction programs but do not get any reduction programs. They assume that the government is impartial in providing poverty reduction programs.

This condition strengthens the thesis that the poverty reduction program in Batam has not been appropriately implemented. This is proof that there are still recipients of poverty reduction programs that do not meet the criteria set by the government. Unwittingly the implementation of this poverty reduction program gave birth to acts of discrimination. Discrimination in question is the difference in treatment between lowincome families who become permanent residents and low-income families who are not permanent residents. Poor people who are not permanent residents tend not to be the main priority to receive or get poverty reduction programs. Even though the non-permanent poor are usually non-permanent residents because they do not yet have their own house or they still rent a house as a place to live, so it is still possible to move around. Economically, the temporary sparse population is far more miserable than the permanent poor population. 
Facts on the ground show that there are still a lot of poor people who are not permanent is more feasible to get poverty reduction programs but do not get it. As a result, social jealousy occurs amid society, especially among poor residents who are permanent or poor residents who are not permanent.

\section{Incumbent Electability Increases}

As stated in the previous section, politically, this poverty reduction program is indeed beneficial for incumbents, both the president, governors, and regents/mayors because this program receives good appreciation from the community, especially the target group and can increase the incumbent's electoral effect. This appreciation automatically increases incumbent electability both at the regional level (governors and regents/mayors) and at the center, namely the president. The researcher found social facts that the majority of the target group did not know the origins of poverty reduction programs, including the sources of funding for poverty reduction programs so that they considered all incumbents worthy to receive their gratitude. One form of reciprocation is to give their political rights to incumbents both at the level and in the ballot box when the general election takes place.

The increasing popularity and electability of incumbents not only in poverty reduction program target groups, but also increases in families, colleagues, or the general public who assess incumbents to have policies/programs that favor the community. Social facts on the ground show that the target group, family, relatives, friends, neighbors, and the general public who are concerned about the issue of poverty stated their political choice to elect incumbents during the presidential and regional elections.

\section{Conclusion}

Based on the results of the research and discussion above, it can be concluded that the poverty reduction programs referred to in this study have five impacts on public problems. First, poverty reduction program interventions have not been able to reduce poverty in Batam. This is proven by the last three years the number of poor people in Batam has increased significantly. Secondly, the target group feels their life is better after receiving poverty reduction programs. Third, the target group continues to live in poverty. This is proven by the absence of poverty reduction program recipients who are meant to be able to get themselves out of poverty. One of the causes is that these poverty reduction programs 
do not provide education and stimulation so that those low-income families can get out of the poverty line. Fourth, the target group has resigned themselves to living in poverty. Although the amount of money, goods, or services they received has not been able to fulfill all their daily lives, they are very grateful for the program. Fifth, some of the target groups (low-income families) surrender to poverty because they think poverty is a destiny that cannot be changed. One reason is that the target group did not receive education and stimulation so that they could get out of poverty. Furthermore, in situations or groups outside the target group or commonly referred to as abundant impacts (externalities or spillover effects), the poverty reduction program in Batam City has two impacts. First, the emergence of social jealousy amid society. This jealousy is triggered by a large number of poor people, especially the poor who are not permanent residents who do not get or receive the poverty reduction programs in question. Besides, it was still found in the field that there were recipients of poverty reduction programs that were considered unfit because they were economically capable. Second, incumbent electability is increased. Whether we realize it or not, like it or not, the poverty reduction program has an electoral effect on incumbents both in the area and in the center.

Based on the above conclusions, the researchers provide some recommendations as follows:

1. The poverty reduction program referred to in this study needs to be continued, but the program requires revision of the substance of the policy or program. One improvement in the revision point is to add elements of education and stimulation to the target group or low-income families, so that poor families have a sense of optimism and are eager to escape from the cycle of poverty. Stimulation in question can be in the form of material such as additional nominal money or goods received that can increase their productivity and in the form of immaterial such as motivation so that they have optimism and more enthusiasm in looking at the future.

2. The central and regional governments are expected to be more massive in involving academics and policy analysts in formulating poverty reduction programs so that the program can more effectively solve the problem of poverty.

3. The government, especially the Batam city government, through social services and other related agencies, is expected to carry out regular supervision of the 
implementation of poverty reduction programs and to regularly update the Integrated Database Data (BDT) in order to minimize the recipient of programs that are not on target.

4. Researchers who have an interest in the problem of poverty can continue this research by examining poverty reduction programs one by one and using different models and theories to get a broader perspective on the problem of poverty reduction.

\section{References}

Arif Nursaid, A. A. (2016). Peran Kelompok Batik Tulis Giriloyo Dalam Mendukung Ketahanan Ekonomi Keluarga ( Studi Di Dusun Giriloyo, Desa Wukirsari, Kecamatan Imogiri , Kabupaten Bantul, Daerah Istimewa Yogayakarta). Jurnal Ketahanan Nasional, 22(2), 217-236.

Dedi Dhosa, D. (2017). Akumulasi Kapital, Penghancuran Gerakan Kiri, dan Kemiskinan di Nusa Tenggara Timur. Jurnal Pemikiran Sosiologi, 4(2), 19-35.

Ermasari, A., Sukamdi, \& Tukiran. (2010). Dinamika Kemiskinan di Jawa Madura Menurut Kabupaten / Kota Tahun 2002 - 2007. Majalah Geografi Indonesia, 23(1), 1-18.

Fajarwati, A., Sari, E. L. P., \& Soewarno, N. G. P. (2017). Strategi untuk Mengatasi Permasalahan Wanita Rawan Sosial Ekonomi (WRSE). Majalah Geografi Indonesia, 31(1), 22. https://doi.org/10.22146/mgi.24227

JPG. (2018, May). Batam Memiliki Penduduk Miskin Terbesar di Kepri. Batam Pos.

Kurniawan, S., Wijaya, A. F., \& Domai, T. (2014). Evaluasi Kinerja Program Pengentasan Kemiskinan ( Studi Program Anti Kemiskinan Bidang Pertanian di Kabupaten Tuban ). Wacana, 17(3), 117-125.

Leslie, L. F., \& Hardyastuti, S. (2011). Analisi Ekonomi Rumah Tangga Petani Nelaayan dalam Mendukung Strategi Penghidupan Berkelanjutan Kawasan Pantai Baron Kabupaten Gunungkidul. Agro Ekonomi, Vol. 18, pp. 94-104.

Mahaeni, A., Sudibia, I. K., Wirathi, I., Rustariyuni, S. D., Putu, N., \& Dewi, M. (2011). Evaluasi Program Pengentasan kemiskinan di Provinsi Bali. Piramida, X(1), 8-18.

Murdiansyah, I. (2014a). Evaluasi Program Pengentasan Kemiskinan Berbasis Pemberdayaan Masyarakat ( Studi Kasus Pada Program Gerdu-Taskin di Kabupaten 
Malang ). Jurnal WIGA, 4(1), 71-92.

Murdiansyah, I. (2014b). Evaluasi Program Pengentasan Kemiskinan Berbasis Pemberdayaan Masyarakat (Studi Kasus Pada Program Gerdu Taskin di Kabupaten Malang). Jurnal WIGA, 4(1), 71-92.

Permana, R. (2016). Faktor-Faktor Yang Mempengaruhi Tingkat Kemiskinan Di Provinsi Kalimantan Timur. Jurnal Ekonomi, Manajemen Dan Akuntansi, 18(2), 111-129.

Pitoyo, A. J., \& Alfana, M. A. F. A. (2015). Strategi Rumah Tangga Miskin Perdesaan Keluar dari Kemiskinan: Kasus Tiga Desa di Kulon Progo, Daerah Istimewa Yogyakarta. Populasi, 23(2), 55-70.

Prastyo, A. A. (2010). Analisis Faktor-Faktor Yang Mempengaruhi Tingkat Kemiskinan.

Romus, M. (2014). Evaluasi Program Pengentasan Kemiskinan Ditinjau Dari Proses Pemberdayaan Ekonomi Pada Kegiatan Pnpm Mandiri Perdesaan Teluk Belitung Kabupaten Kepulauan Meranti. Jurnal El Riyasah, 5(4).

Roso Wulandari, N. (2016). Faktor-Faktor Yang Mempengaruhi Kemiskinan Rumah Tangga

Di Kota Kendari Tahun 2014. Jurnal Progres Ekonomi Pembangunan, 1(1), 111-119.

Rusdianto. (2018, March). Gubernur akui tingkat kemiskinan kepri meningkat. antarakepri.

Saptono, A., Program, E., Kemiskinan, P., Kasus, S., Ekonomi, P., Perkotaan, P. M., ... Jawa,

B. (2013). Evaluasi Program Pengentasan Kemiskinan (Studi Kasus Pemberdayaan

Ekonomi pada Program Nasional Pemberdayaan Masyarakat (PNPM) Mandiri

Perkotaan di Kelurahan Perwira Kecamatan Bekasi Utara Kota Bekasi Jawa Barat). Econo Sains, XI(2), 29-54.

Satyagraha. (2018, January). Jumlah penduduk miskin Indonesia 26,58 juta orang. Antaranews.Com.

Sugiyono. (2016). Metode Penelitian Kuantitatif, Kualitatif, dan RED. Bandug: Alfabeta.

Surahmiyati, S., Yoga, B. H., \& Hasanbasri, M. (2017). Dukungan sosial untuk orang dengan gangguan jiwa di daerah miskin : studi di sebuah wilayah puskesmas di Gunungkidul. Berita Kedokteran Masyarakat, 33(8), 403-410.

Taufiqurokhman. (2014). Kebijakan Publik (Cetakan Pe). Fakultas Ilmu Sosial dan Ilmu Politik Universitas Moestopo Beragama Pers.

Winarno, B. (2016). Kebijakan Publik Era Globalisasi: Teori, Proses, dan Studi Kasus Komparatif. Caps. 
Yendriwalis, R. (2015). Evaluasi Program Pengentasan Kemiskinan di Provinsi Kepulauan Riau. Universitas Maritim Raja Ali Haji.

Zuhdiyaty, N., \& Kaluge, D. (2017). Analisis Faktor-faktor yang Mempengaruhi Kemiskinan di Indonesia Selama Lima Tahun Terakhir (Studi Kasus Pada 33 Provinsi). Jibeka, 11(2), 27-31. 